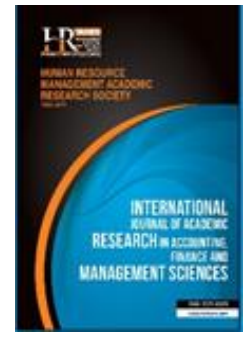

International Journal of Academic Research in Accounting, Finance and Management Sciences

Vol. 8, No.2, April 2018, pp. 143-154

E-ISSN: 2225-8329, P-ISSN: 2308-0337

(c) 2018 HRMARS

www.hrmars.com

To cite this article: Faraj Aldaihani, F.M., Bin Ali, N.A. (2018). Effect of Electronic Customer Relationship Management on Electronic Service Quality Provided by the Commercial Banks in Kuwait, International Journal of Academic Research in Accounting, Finance and Management Sciences 8 (2): 143-154 http://dx.doi.org/10.6007/IJARAFMS/v8-i2/4239 (DOl: 10.6007/JJARAFMS/v8-12/4239)

\title{
Effect of Electronic Customer Relationship Management on Electronic Service Quality Provided by the Commercial Banks in Kuwait
}

\author{
Faraj Mazyed FARAJ ALDAIHANI ${ }^{1}$, Noor Azman BIN ALI ${ }^{2}$ \\ ${ }^{1}$ Department of Marketing, Faculty of Economics and Management, University Putra Malaysia, \\ 43400 UPM Serdang, ${ }^{1}$ E-mail: f.airforc@hotmail.com \\ ${ }^{2}$ Department of Management and Marketing, Faculty of Economics and Management, University Putra Malaysia, \\ 43400 UPM Serdang, ${ }^{2}$ E-mail: nazmn@upm.edu.my
}

\begin{abstract}
The study aims to investigate the impact of electronic customer relationship management on Electronic service quality provided by the commercial banks in Kuwait. The study population consisted of all of the customers of the commercial banks in Kuwait. A convenience sampling was taken from customers of the commercial banks in Kuwait and using the electronic services provided by banks that estimated (541) respondents. To achieve the objectives of the study, the descriptive analytical method was used through A questionnaire that used a major tool for data collection developed at the hands of elite researchers and writers in the field of the study variables and which consisted of (39) items. A number of statistical tools and methods were used such as Mean, Standard Deviation, one sample T-test, Multiple Regression. After the analysis of the collected data and hypotheses, a number of results were reached: There was a significant impact of E-customer relationship management on Electronic service quality provided by the commercial banks in Kuwait. Based on the findings of the present study, the researcher recommends managers and decision makers of the commercial banks in Kuwait to know how to use their website to market services that will be considered valuable by customers.

Key words

Electronic Customer Relationship Management, electronic service quality, commercial banks, Kuwait

Received: 16 May 2018 (c) The Authors 2018

Revised: 02 Jun 2018 Published by Human Resource Management Academic Research Society (www.hrmars.com)

Accepted: 10 Jun 2018 This article is published under the Creative Commons Attribution (CC BY 4.0) license. Anyone may Published Online: 26 Jun 2018 This article is published under the Creative Commons Attribution (CC BY 4.0) license. Anyone may
reproduce, distribute, translate and create derivative works of this article (for both commercial and noncommercial purposes), subject to full attribution to the original publication and authors. The full terms of this license may be seen at: http://creativecommons.org/licences/by/4.0/legalcode
\end{abstract}

\section{Introduction}

In light of the rapid development of information and communication technology in the economy and business world in the twenty-first century. The past years have seen a wide spread of the Internet, and it has become possible to interact immediately where you are, any time, and at low cost, as the global market shifted from a tangible market orientation to the space market. In the line with the technological revolution, the State of Kuwait has witnessed a development in various economic fields. The development of the Kuwaiti banking sector is considered one of the most important aspects of economic progress. Kuwaiti banks have reached the advanced stage of using modern technology and adapting them to provide electronic banking services to customers using fast communication systems, and advanced information network In terms of inclusiveness and protection, as it is able to keep abreast of developments in developed countries in the field of banking, and it became necessary to pay attention to the quality of electronic service in the context of global competitiveness, The quality of e-service means the extent to which the website facilitates the sale, purchase and delivery of services and products with high efficiency. It 
also achieves the efficiency of online mobility and increases the volume of data and information provided to the customer.

The use of Internet in marketing offers huge opportunities for marketers to develop innovative strategies that were not previously possible. However, marketers need to develop a broad understanding of customer behavior when they purchasing products online, so marketing managers need customer relationship management programs as requirements to improve and meet the customer's desires and needs. Communication technology enables companies to communicate with their customers in more efficient and efficient ways. As a result, companies have become more efficient in managing their customer relationships, especially with the use of the Internet. CRM has also been seen as an application centered on call centering and selling as a centralized automated power (Goldenberg, 2000). Scullin et al. (2002) noted that the rush to implement CRM systems came from the companies' desire to deliver huge benefits from high return on investment (ROI), increased customer loyalty.

Recent decades have witnessed a radical transformation in the financial and banking sector. As a result of the revolution in the field of information and communication technology, several new ways of providing banking services to customers have emerged (Al-Hawary and Metabis, 2012). It is one of the most widely used distribution channels in financial services institutions (Fonchamnyo, 2012). On the other hand, the banking sector is one of the main pillars of the economy in all countries of the world, and given the challenges faced by the business environment in the financial services market; this has increased pressure on banks to develop alternative channels beyond the traditional performance. And does not adhere to a specific place or time in their financial transactions in order to attract more customers, and improve customer perceptions about the services provided by this sector. As the banking sector was one of the sectors most closely aligned with technological developments in order to increase the efficiency and effectiveness of its performance, it had to benefit from the ICT revolution and its use through electronic banking services (Al-Hawary and Metabis, 2013; Essam et al., 2006).

The quality of e-service is characterized by the ability to use it in the event of any problems in the central service, which is a remedial service that solves problems in case of any need for any help. The quality of e-service is one-dimensional. Technology readiness has an impact on the perception of e-service quality, customer satisfaction, and procurement and decision-making (Zeithaml et al., 2002).

Most previous studies focused on impact of E-CRM on loyalty, satisfaction, performance. Furthermore, the very few studies attempting to develop a more complete model were cross-sectional, providing little evidence of the effects of E-CRM on e-service quality, in addition to the absence of comprehensive theoretical models of those characteristics related to the management of electronic customer relationship management and their impact on e-service quality. This requires more studies in order to get a better understanding of this impact, so the current study attempts to fill this gap by investigate the impact of e-customer relationship management on e-service quality of the commercial banks in Kuwait.

\section{Theoretical framework and hypotheses development}

\subsection{Electronic customer relationship management}

Customer Relationship Management (CRM) is a wide-ranging application that encompasses many of the company's business, focuses on customers. It is a continuous effort and requires a redesign of core operations in the company's business, starting from the point of view of customers based on what the company receives from customer feedback. Therefore, the development of products and services based on this approach must necessarily match the needs of the customers (Al-Hawary and Aldaihani, 2016). In addition, improving customer relationships requires a full understanding of all customer sectors, whether profitable or unprofitable, and then the company's business processes must be organized to treat customers on an individual basis, and to meet their needs and desires according to their values and beliefs (Renner, 2000).

Both technology and processes are critical to the creation of successful customer relationship management initiatives. Employees are the building blocks of customer relationship building, and each employee must understand the purpose of establishing customer relationship management and the changes it will bring to the company (Chen and Popovich, 2003). For example, a client-centered 
reengineering model requires cultural change and the participation of all employees within the company. Some employees may want to leave the job; others will be opposed to the new business model, so the successful implementation of CRM will mean that some jobs will make a significant difference (Al-Mashari and Zairi, 2000). Top management should demonstrate commitment to an ongoing corporate development and training program. In addition to enhancing the skills of knowledge and learning to workers, which in turn enhances the motivation and commitment of workers and reduces their resistance.

Purba (2001) defined electronic relationship management as an application based on Internet technology to achieve customer relationship management objectives. Yaeckel et al. (2002) noted that if CRM is successfully implemented, customers have access to information and services on products that are less expensive and more convenient than what they receive through traditional methods. Therefore, ecustomer management is a tool to help customers evaluate and buy products effectively. They believe that customers through e-CRM use self-service tools to search the Internet rather than directly caring for employees, thus increasing service and purchasing activity.

CRM applications are designed to include the entire company including all customers, suppliers and partners. E-CRM also supports solutions for marketing, selling and service activities (Pan and Lee, 2003). In the field of online marketing, the primary goal of any company is to maintain a relationship with its customers. CRM is the tool that enables the company to achieve this goal. With appropriate implementation of CRM, the following benefits can be achieved: increased customer loyalty, improved customer service and support, increased efficiency and lower costs (Scullin et al., 2002). The cost is reduced through e-CRM as a result of the elimination of physical intervention and the integration of customer data into a single database, which allows marketing teams, sales teams and other departments within the company to share information and work to achieve the company's common goals using the same basic customer statistics.

\subsection{Dimensions of Electronic customer relationship management}

The review of many of the studies that attempted to measure the dimensions of electronic customer relationship management indicates that there are many acceptable measures, in this study Website design, the ability to search, privacy and security, and delivery time were considered to be the dimensions of electronic customer relationship management.

Website design: It is defined as the general image of the personality of organization to deal with the electronic sales of customers through the introduction and use of models, colors and logos on the site. Website design as the image that shows where the bank website in the mind of customers and the goal of the aesthetic website design is to make it attractive and fun for the customer in terms of visuals (Ahmad and al-Zu'bi, 2011). The design includes: organization of the site, products offered and product prices, providing online purchasing and shipment tracking features that have a positive impact on electronic satisfaction and customer preferences on the Internet.

The ability to search: refers to the special advantage of the website, including the presentation of the company's products and characteristics when the customer wants to see a large number of criteria in the selection of the product to facilitate and support the decision of the customer in the decision-making process appropriate for him.

Privacy and security: refers to the security of the website of the organization companies in terms of its ability to protect the personal information of customers from unauthorized use or disclose their personal information in a manner that may affect their decision to conduct transactions through the company's website.

Delivery time: Indicates the ability of the organization to deliver products on time to the customer, resulting in a positive effect in removing doubts and distrust in e-shopping online and supports confidence in the company's website and gives the customer a sense of comfort and encourages him to buy from the same site In many times.

\subsection{Electronic service quality}

The service quality has become very important due to the increasing preparation of service organizations and the growing competition among them, where it is no longer sufficient to provide services 
at reasonable quality and price without the provision of good treatment and understanding of the largest customers with the concern of organizations to continue to deal with them and expand its customer base (Alshurideh et al., 2017). The quality of the banking service is a crucial factor in determining the competitive position, and achieving excellence of the banks customers (Al-Hawary, 2013a; Al-Hawary, 2013b). Parasuraman et al. (2005) defines service quality as "comparing the customer to his current experience with the service in his previous experiences in dealing with similar services". As Grnroos (1982) defines service quality as "customer awareness of the difference between the expected service and the perceived service. Based on many studies, most modern service quality definitions focus on two main pillars: customer expectations and customer perception of the service actually provided (Al-Hawary, 2012). Quality of service can be measured by asking the following question to customers: Was the service provided in line with their expectations or better or worse than those expectations?

Electronic service quality (e-SQ) is defined by Zeithaml et al. (2000) as "the extent to which a Web site facilitates efficient and effective shopping, purchases and delivery of products and services". According to Santos electronic services quality can be defined as general consumer's judgment and evaluation of quality and superiority of electronic services presented in virtual market (Santos, 2003). It has been defined as, e-service quality as website interactions that facilitate an effective purchasing, shopping and delivery experience. According to Rust et al. (1995) electronic services mean presenting services on electronic networks like internet which consist provided services by both service organizations and product producers that their success depends on provided services quality by them. Zeithaml et al., (2002) introduced the concept electronic service quality (e-SQ) and their role in service quality delivery to customers. They provided the first formal definition of e-SQ. They define service quality as "the extent to which a website facilitates efficient and effective shopping, purchasing and delivery of products and services".

\subsection{Electronic service quality measurements}

The review of many of the studies that attempted to measure the service quality indicates that there are two acceptable parameters. The first is the scale that depends on the expectations of the beneficiaries for the level of service and their understanding of the level of performance of the service actually provided, and the determination of the congruence or the gap between expectations and perceptions (Al-Hawary and Abu-Laimon, 2013). The actual service provided to the customer on the basis that the quality of service is expressed as a kind of trends and is characterized by simplicity and ease (Constant, 1996). In the opinion of the researchers, it is not possible to establish consistent standards to measure the quality of service and dissemination to all organizations and service companies, but there is an urgent need for each service sector to develop appropriate standards to measure the quality of service provided in the light of the circumstances, Achieving a balance between the goals of the customer, the service provider and the service organization at the same time, but this does not prevent the existence of common standards that can be applied to some similar or similar service organizations (Al-Hawary and Metabis, 2013). Past studies identified several dimensions for measuring e-service quality in different contexts. The table 1 below shows the studies that dealt with dimensions of e-service quality.

Table 1. the dimensions of electronic service quality as adopted by authors

\begin{tabular}{|c|l|}
\hline Author & \multicolumn{1}{|c|}{ Dimensions } \\
\hline Al-Hawary and Al-Menhaly (2016) & $\begin{array}{l}\text { (website design), (reliability), (responsiveness), (security and privacy), } \\
\text { (availability of information), (ease of use) }\end{array}$ \\
\hline Al-Hawary and Al-Smeran (2016) & $\begin{array}{l}\text { (Reliability), (Ease of use), (Effectiveness), (Web Site Design), (privacy), and } \\
\text { (Responsiveness) }\end{array}$ \\
\hline Abbad et al. (2012) & (Reliability) ‘(Efficacy and Effectiveness) ‘(Security) ‘(Privacy),(Differentiation). \\
\hline Al-Hawary and Metabis, 2013 & (Reliability) ‘(Responsiveness) ‘(Security) ‘(Empathy) ‘(Tangibility) \\
\hline Barnes and Vidgen (2002) & (Usability), (design), (information), (trust), (empathy). \\
\hline Swaid and Wigand, 2009 & $\begin{array}{l}\text { (Information Quality) ‘(Ease of Use) ‘(Reliability) ‘(Responsiveness) ‘(security) ‘ } \\
\text { (Personalization) }\end{array}$ \\
\hline Ma et al. (2012) & (Website quality) ‘(Privacy) ‘(Security) ‘(Ease of Use) ‘(Fulfillment). \\
\hline Santos (2003) & $\begin{array}{l}\text { (ease of use), (appearance), (linkage), (structure and layout), (content), } \\
\text { (reliability), (efficiency), (support), (communication), (security), (incentive) }\end{array}$ \\
\hline
\end{tabular}




\begin{tabular}{|c|c|}
\hline Chu et al. (2012) & $\begin{array}{llll}\begin{array}{l}\text { (Efficiency) ‘(Reliability,) } \\
\text { ‘Compensation). }\end{array} & \text { (Fulfillment) } & \text { ‘(Privacy) } & \text { (Responsiveness)( } \\
\end{array}$ \\
\hline Lee and Lin, 2005 & (Website Design) ‘(Reliability) ‘(Responsiveness) ‘(Trust) ‘(Personalization) \\
\hline Alam and Kuppusamy (2008) & $\begin{array}{l}\text { (ease of use), (appearance), (reliability), (customization), (communication), } \\
\text { (incentive) }\end{array}$ \\
\hline Cletus (2012) & (Security) ،(Trust) ،(Cost of Service) ‘(Usefulness ‘(Accessibility). \\
\hline Zeithaml et al. (2002) & $\begin{array}{l}\text { (Information Availability) ‘(Content) ‘(Privacy) ‘(Security) ‘(Website Graphic } \\
\text { Style) ‘(Usability) ‘(Fulfillment). }\end{array}$ \\
\hline Hassanuddin et al. (2012) & (Ease of Use) ‘(Security) ‘(Privacy) ‘(Quality of Internet Connection). \\
\hline
\end{tabular}

Based on the above, the researchers dealt with the dimensions of the electronic service quality in accordance with the study population which was conducted. A number of Arab and foreign references were used in determining the dimensions, namely Ease of Use, Usefulness, Cost, and Accessibility.

Ease of use: The ease of use of the website is a justification for the customer's dealing with the bank in the use of electronic banking services, and a factor in assessing the quality of electronic service (AlHawary and Hussien, 2016). It can be defined as the customer's perception of the level of ease of a system (Hijzazi, 2011). It can be defined as the customer's ability to experiment with a new innovation and benefit from its advantages more easily (Al-Smadi, 2011). It was defined by Salhieh et al. (2011) as the degree of customer expectation about the ease of a particular system and free of effort.

Usefulness: This dimension means the benefit that the electronic banking system can achieve and its contribution to enhancing efficiency and overall performance, which enables them to benefit from the advantages of banking services more easily and quickly. Cletus (2012) defines usefulness as the ability of the electronic system to improve banking transactions compared to the traditional method. It can also be defined as the degree to which people believe that the use of a particular system enhances job performance (Salhieh et al., 2011). The use of the e-banking system improves the way they access the service and the ability of the system to meet the customers' expectations and their effectiveness in solving their problems in order to create customers loyalty (Al-Hawary and Al-Smeran, 2016).

Cost of use: This dimension is characterized by the ability of the banking service to reduce the total costs for both the customer and the bank compared to the traditional banking method (Rosu, 2011). Jazani et al. (2012) indicated that e-Banking has succeeded in reducing operational and administrative costs, which has led to customer satisfaction on e-banking, and maintained a long-term relationship between the Bank and the customer. It has been defined by Jazani et al. (2012) as the Organization's ability to reduce operational and administrative costs in an electronic manner.

Accessibility: Amish (2005) defines it as the ability of the user to access the information or service through website, allowing the customer to move through the website in an orderly manner, and enable them to access the banking service at any time and place. Cletus (2012) refers to the concept of accessibility to the extent to which customers can access electronic banking services in the appropriate time, such as cash withdrawal, transfer, deposit and loan demand, and can be defined as the ability of users to access information and services online (Ala` Eddin et al. , 2011).

\subsection{Research hypotheses}

Based on the above literature reviewed, the research hypothesis is:

$H$ : Electronic customer relationship management influence electronic service quality provided by the commercial banks in Kuwait

More specifically:

H1a. Website design directly influences electronic service quality provided by the commercial banks in Kuwait.

H1b. Search ability directly influences electronic service quality provided by the commercial banks in Kuwait.

H1c. Privacy and security directly influences electronic service quality provided by the commercial banks in Kuwait.

H1d. Delivery time directly influences electronic service quality provided by the commercial banks in Kuwait. 


\subsection{Research Framework}

Based on the study hypothesis, the following theoretical framework shown in Figure 1. As can be seen from the framework, the study investigates the impact of Electronic customer relationship management on electronic service quality provided by the commercial banks in Kuwait, where electronic customer relationship management is the independent variable and are positively related to electronic service quality as the dependent variable.

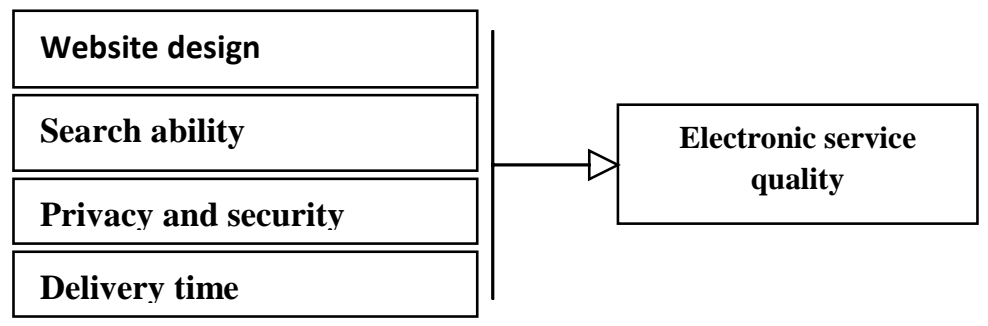

Figure 1. Theoretical Model

\section{Methodology of research}

\subsection{Study tool}

Based on the literature review, and the previous studies, researchers have developed a questionnaire to collect data from the study population, which contains three sections. The first section consisted of a list of questions intended to probe the demographic variables of the respondents (gender, age). The second section was comprised 20 items used to measure electronic customer relationship management, adopted from previous studies (Wang and Liao, 2007; Fjermestad and Romano,2002; Lee-Kelley et al., 2003), and which could possibly influence electronic service quality, using a five-point Likert scale with anchors strongly disagree $(=1)$ and strongly agree $(=5)$. All items were positively worded.. The following practices were focused on; Website design ( 6 statements), ability to Search on Website (5 statements), Privacy and security ( 4 statements), and Delivery time ( 5 statements). While the third section contained 19 items to measure electronic service quality consist of four dimensions Ease of Use ( 6 statements), Usefulness ( 5 statements), Cost (4 statements), and Accessibility (4 statements), adopted from previous studies (Cristobal et al., 2007; Al-Hawary, and Al-Smeran, 2016; Al-Hawary and Hussien, 2016). Data are collected using a questionnaire.

\section{2. population and Sample}

The study population consisted of all of the customers of the commercial banks in Kuwait. A convenience sampling was taken from customers of the commercial banks in Kuwait and using the electronic services provided by banks, with reference to the sample schedule (Bartlett et al.,2002), a sample of 600 customers were selected to represent the study population, the researchers distributed the questionnaires to the study sample. (564) questionnaires retrieved. After reviewing the questionnaires show that there are (23) extremely unfit for statistical analysis, that had the study sample size (541).

Table 2. Sample characteristics

\begin{tabular}{|l|l|c|c|}
\hline Variable & & Frequency & $\%$ \\
\hline \multirow{4}{*}{ Age group } & less than 25 & 66 & 12.16 \\
\cline { 2 - 4 } & 25- less than 35 & 223 & 41.21 \\
\cline { 2 - 4 } & 35- less than 45 & 113 & 20.89 \\
\cline { 2 - 4 } & 45- less than 55 & 106 & 19.59 \\
\cline { 2 - 4 } & 55 and more & 33 & 6.10 \\
\hline \multirow{5}{*}{ Gender } & Male & 316 & 58.41 \\
\cline { 2 - 4 } & Female & 225 & 41.59 \\
\hline \multirow{2}{*}{ Educational level } & Less than Bachelor & 63 & 11.65 \\
\cline { 2 - 4 } & Bachelor & 369 & 68.21 \\
\hline
\end{tabular}


Higher study

109

20.15

Females make (41.59 percent) of the customers on the other hand Males respondents represented (58.41 percent) of the sample. The largest group of respondents (41.21 percent) was aged 25 - less than 35. The next largest group (20.89 percent) was aged 35- less than 45. Smaller groups of respondents were aged 55 and more (6.10 percent). With regard to educational level, respondents with Bachelor degrees were the largest group of respondents make (68.21 percent), respondents with Less than Bachelor make (11.65 percent). Finally, respondents with higher study degrees make (20.15 percent). The characteristics of the sample represented in Table 2.

\subsection{Reliability and validity of the survey instrument}

The survey instrument with 39 items was developed based on two variables Electronic customer relationship management as independent variables with four dimensions; Website design (WEB1-WEB6), ability to search on Website (ASW7-ASW11), Privacy and security (PS12-PS15), and Delivery time (DEL16DEL20). Electronic service quality as dependent variables consists of four dimensions; Ease of Use (EU1EU6), Usefulness (US7-US11), Cost (CO12-CO15), and Accessibility (AC16-AC19). The instrument was evaluated for reliability and validity. Reliability refers to the instrument's ability to provide consistent results in repeated uses (Gatewood and Field, 1990). Validity refers to the degree to which the instrument measures the concept the researcher wants to measure (Bagozzi and Phillips, 1982).

Table 3. Factor analysis of Electronic customer relationship management

\begin{tabular}{|c|c|c|c|c|c|}
\hline Construct and item & Loadings & Communalities & KMO & Variance & Reliability \\
\hline Website design (WEB) & & & .639 & 71.624 & 0.88 \\
\hline WEB1 & 0.63 & 0.69 & & & \\
\hline WEB2 & 0.65 & 0.68 & & & \\
\hline WEB3 & 0.62 & 0.65 & & & \\
\hline WEB4 & 0.66 & 0.69 & & & \\
\hline WEB5 & 0.71 & 0.74 & & & \\
\hline WEB6 & 0.72 & 0.76 & & & \\
\hline ability to Search on Website (ASW) & & & .711 & 55.687 & 0.85 \\
\hline ASW7 & 0.59 & 0.63 & & & \\
\hline ASW8 & 0.56 & 0.62 & & & \\
\hline ASW9 & 0.61 & 0.68 & & & \\
\hline ASW10 & 0.63 & 0.67 & & & \\
\hline ASW11 & 0.66 & 0.70 & & & \\
\hline Privacy and security (PS) & & & .813 & 64.321 & 0.81 \\
\hline PS12 & 0.61 & 0.64 & & & \\
\hline PS13 & 0.59 & 0.62 & & & \\
\hline PS14 & 0.58 & 0.61 & & & \\
\hline PS15 & 0.55 & 0.59 & & & \\
\hline Delivery time (DEL) & & & .781 & 61.357 & 0.84 \\
\hline DEL16 & 0.55 & 0.58 & & & \\
\hline DEL17 & 0.61 & 0.64 & & & \\
\hline DEL18 & 0.66 & 0.70 & & & \\
\hline DEL19 & 0.64 & 0.69 & & & \\
\hline DEL20 & 0.70 & 0.74 & & & \\
\hline
\end{tabular}

Table 4. Factor analysis of electronic service quality

\begin{tabular}{|c|c|c|c|c|c|}
\hline Construct and item & Loadings & Communalities & KMO & Variance & Reliability \\
\hline Ease of Use (EU) & & & .643 & 69.543 & .87 \\
\hline EU1 & 0.61 & 0.64 & & & \\
\hline EU2 & 0.59 & 0.62 & & & \\
\hline EU3 & 0.58 & 0.61 & & & \\
\hline EU4 & 0.71 & 0.76 & & & \\
\hline EU5 & 0.72 & 0.75 & & & \\
\hline
\end{tabular}




\begin{tabular}{|c|c|c|c|c|c|}
\hline Construct and item & Loadings & Communalities & KMO & Variance & Reliability \\
\hline EU6 & 0.55 & 0.59 & & & .88 \\
\hline Usefulness (US) & & & .716 & 70.286 & \\
\hline US7 & 0.56 & 0.59 & & & \\
\hline US8 & 0.55 & 0.58 & & & \\
\hline US9 & 0.51 & 0.53 & & & \\
\hline US10 & 0.58 & 0.61 & & & \\
\hline US11 & 0.61 & 0.64 & & 68.576 & \\
\hline Cost (CO) & & & & \\
\hline CO12 & 0.61 & 0.64 & & & \\
\hline CO13 & 0.62 & 0.68 & & & \\
\hline CO14 & 0.59 & 0.62 & & & \\
\hline CO15 & 0.57 & 0.60 & & & \\
\hline Accessibility (AC) & & & & & \\
\hline AC16 & 0.62 & 0.68 & & & \\
\hline AC17 & 0.63 & 0.69 & & & \\
\hline AC18 & 0.68 & 0.72 & & & \\
\hline AC19 & 0.66 & 0.70 & & & \\
\hline
\end{tabular}

Factor analysis and reliability analysis were used in order to determine the data reliability for the Electronic customer relationship management, and electronic service quality. A within factor, factor analysis was performed to assess convergent validity. The results of the factor analysis and reliability tests are presented in Table 3 and Table 4. All individual loadings were above the minimum of 0.5 recommended by Hair et al. (1998). For exploratory research, a Chronbach $\alpha$ greater than 0.80 is generally considerate reliable (Nunnally, 1978). Chronbach $\alpha$ statistics for the study contracts are shown in Table 3 and Table 4. Thus it can be concluded that the measures used in this study are valid and reliable. Kaiser-Meyer-Olkin has been used as Pre-analysis testing for the suitability of the entire sample for factor analysis as recommended by Comrey (1978), the value of The Kaiser-Meyer-Olkin measure was used to assess the suitability of the sample for each unifactorial determination. The KMO values found (see Table 3 and 4) are generally considered acceptable (Kim and Mueller, 1978). All factors in each unifactorial test accounted for more than 55.687per cent of the variance of the respective variable sets. This suggests that only a small amount of the total variance for each group of variables is associated with causes other than the factor itself.

\subsection{Descriptive statistics analysis}

Table 5 indicates that the customers of the commercial banks in Kuwait evaluate electronic customer relationship management with high degree $(M=3.85)$, with regards to Delivery time has got the highest degree $(M=3.92, S D=0.69)$, followed by Website design $(M=3.87, S D=0.56)$, Privacy and security $(M=3.85$, $S D=0.65)$, and Search ability on Website with the degree $(M=3.75, S D=0.54)$. With regard to electronic service quality, of the commercial banks in Kuwait evaluate the quality of electronic service provided by commercial banks with high degree $(M=3.84)$. With regards to Cost has got the highest degree $(M=3.91$, $\mathrm{SD}=0.59)$, followed by Ease of Use $(M=3.88, S D=0.71)$, Accessibility $(M=3.81, S D=0.62)$, and Usefulness with the lowest degree $(M=3.76, S D=0.64)$.

Table 5. Descriptive analysis of Electronic customer relationship management and electronic service quality

\begin{tabular}{|l|c|c|}
\hline \multicolumn{1}{|c|}{ Dimension } & Mean & Standard deviation \\
\hline Electronic customer relationship management & 3.85 & \\
\hline Website design & 3.87 & 0.56 \\
\hline Search ability on Website & 3.75 & 0.54 \\
\hline Privacy and security & 3.85 & 0.65 \\
\hline Delivery time & 3.91 & 0.69 \\
\hline Electronic service quality & 3.84 & \\
\hline Ease of Use & 3.88 & 0.71 \\
\hline Usefulness & 3.76 & 0.64 \\
\hline Cost & 3.91 & 0.59 \\
\hline
\end{tabular}




\begin{tabular}{|c|c|c|}
\hline Dimension & Mean & Standard deviation \\
\hline Accessibility & 3.81 & 0.62 \\
\hline
\end{tabular}

\subsection{Correlation analysis: relationships between the variables}

The correlation matrix in Table 6 further indicates that the correlation coefficients between the independent variables (i.e. electronic service quality) were less than 0.9 , indicating that the data was not affected by a collinearity problem (Hair et al., 1998). These correlations are also further evidence of validity and reliability of measurement scales used in this research (Barclay et al., 1995; Hair et al., 1998).

Table 6. Summary of correlations of Electronic customer relationship management dimensions

\begin{tabular}{|l|c|c|c|c|}
\hline \multicolumn{1}{|c|}{ Variables } & WEB & ASW & PS & DEL \\
\hline Website design & 1 & & & \\
\hline Search ability on Website & $.490\left(^{* *}\right)$ & 1 & & \\
\hline Privacy and security & $.630\left({ }^{* *}\right)$ & $.557\left(^{* *}\right)$ & 1 & \\
\hline Delivery time & $.382\left({ }^{* *}\right)$ & $.349\left(^{* *}\right)$ & $.583(* *)$ & 1 \\
\hline
\end{tabular}

Notes: ${ }^{* *}$ Correlation is significant at the 0.01 level (2-tailed).

\section{Test of hypothesis}

Multiple regression analysis was employed to test the hypotheses. It is a useful technique that can be used to analyze the relationship between a single dependent variable and several independent variables (Hair et al., 1998). In this model, electronic service quality acts as the dependent variable and Electronic customer relationship management, as the independent variables. From the result as shown in Table 7, the regression model was statistically significant $(F=65.364$; $\operatorname{Adj} R 2=.39 ; P=.000)$. The AdjR2 is 0.39 , which means that 39.0 percent of the variation in electronic service quality can be explained by Website design, Search ability on Website, Privacy and security, and Delivery time. The proposed model was adequate as the F-statistic $=65.364$ were significant at the $5 \%$ level $(p<0.05)$. This indicates that the overall model was reasonable fit and there was a statistically significant association between Electronic customer relationship management and electronic service quality.

Table 5 also shows that Website design ( $\beta=0.165, p<0.05)$, Search ability on Website $(B=0.136 ; p<0$, $05)$, Privacy and security $(\beta=0.207, p<0.05)$, and Delivery time $(\beta=0.198, p<0.05)$ had a significant and positive effect on electronic service quality. This provides evidence to support H1a, H1b, H1c, and H1D. Based on the $B$ values Privacy and security has the highest impact on electronic service quality followed by Delivery time, Website design, finally Search ability on Website.

Table 8. Regression Summary of Electronic customer relationship management and electronic service quality $(\mathrm{N}=410)$

\begin{tabular}{|c|c|c|c|c|c|}
\hline \multirow{2}{*}{ Model } & \multirow{2}{*}{$\begin{array}{c}\text { Standardized } \\
\text { coefficients }\end{array}$} & \multirow[t]{2}{*}{$\mathbf{t}$} & \multirow{2}{*}{ Sig. } & \multicolumn{2}{|c|}{ Collinearity statistics } \\
\hline & & & & Tolerance & VIF \\
\hline Website design & 0.165 & 3.228 & 0.002 & 0.361 & 2.77 \\
\hline Search ability on Website & 0.136 & 3.004 & 0.001 & 0.256 & 3.91 \\
\hline Privacy and security & 0.207 & 5.516 & 0.004 & 0.419 & 2.39 \\
\hline Delivery time & 0.198 & 4.352 & 0.000 & 0.502 & 1.99 \\
\hline
\end{tabular}

Notes: R 2 = 0.41; Adj. R 2 = 0.409; Sig. F = 0.000; F-value = 65.364; dependent variable, electronic service quality; $p<0.05$

\section{Discussions}

The results of the study show that commercial banks in Kuwait are clearly interested in the management of electronic customer relations. This is reflected in the design of the bank's website, which reflects the high attractiveness, colors consistent and attractive site and speed in loading pages from the customers' perspective. The website is designed to provide the details required by customers about the various services offered by the bank, which saves the time and effort, customer can browse the electronic sites easily and without complexity and has the knowledge of the latest services provided by the bank, and the Bank is constantly updating the website in line with the developments, in addition to the customer's 
sense of security and confidentiality of personal information and protection of his privacy, which helps the customer to put confidence in the bank, and the desire to continue dealing with the bank, and with confirms the views of customers that the possibility of searching the website on the information is easy, Which helps the customer to complete his financial and banking transactions easily, and to obtain service in the shortest time, and this reflects the ability of the bank to retain the customer, and the desire to ensure the best service to the customer. In addition to easy access to the financial and banking information that the customer is looking for, and the low cost of obtaining the electronic service encourages the customer to communicate electronically with the bank to obtain the service.

The study results show a statistically significant impact of e-customer relationship management (website design, site search, privacy and security, and on-time delivery) on electronic service quality. The convenient design of the website in terms of convenience, attractiveness, comfortable colors, easy access to information, fast delivery of the service helps the customer to search and easily on the financial and banking information, and helps to complete the financial process with the least effort and cost, so customer continues to deal with the bank and is interested in obtaining the e-service which helps in achieving and enhancing the quality of the electronic service. Ease of use as makes the customer accepts using services with no additional cost (Davis et al., 1989; Al-Gahtani, 2001).

\section{Recommendations}

Based on the findings of the present study, the researcher recommends managers and decision makers of the commercial banks in Kuwait to know how to use their website to market services that will be considered valuable by customers, and to develop mechanisms to enhance the use of the website through structuring and updating the websites to make it faster to download the pages, which helps customers to get financial and banking services with least effort and cost. And formulating and implementing e-CRM performance in assessing service providers to assign proportionate amount of resources to achieve sustainable customer loyalty.

\section{References}

1. Abbad, M., Abed, Juma'h M. and Abbad, M. (2012). The Development of E-Banking in Developing Countries in the Middle East. Journal of Finance, Accounting and Management, 3(2), 107-123.

2. Ahmad, A., and Al-Zu'bi, H. (2011). E-banking Functionality and Outcomes of Customer Satisfaction: An Empirical Investigation. International Journal of Marketing Studies, 3(1), 50-65.

3. Ala' Eddin, A. Mohd K. and Al-Zu'bi, H.A. (2011). E-banking Functionality and Outcomes of Customer Satisfaction: An Empirical Investigation. International Journal of Marketing Studies, 3(1).

4. Al-Gahtani, S. (2001). The applicability of TAM outside North America: an empirical test in the United Kingdom. Information Resources Management Journal, 2 (July-September).

5. Al-Hawary, S.I.S. and Abu-Laimon, A.A.A. (2013). The impact of TQM practices on service quality in cellular communication companies in Jordan. Int. J. Productivity and Quality Management. 11(4), 446-474.

6. Al-Hawary, S.I.S. and Metabis, A. (2013). The impact of Internal Marketing Practices on Services Quality of Commercial Banks in Jordan. International Journal of Services and Operations Management (IJSOM). 13(3), 313-337.

7. Al-Hawary, S.I.S. (2012). Health care services quality at private hospitals, from patients' perspective: a comparative study between Jordan and Saudi Arabia, African Journal of Business Management, Vol. 6 No. 22, pp. 6516-6529.

8. Al-Hawary, S.I.S. (2013a). The role of perceived quality and satisfaction in explaining customer brand loyalty: mobile phone service in Jordan. International Journal of Business Innovation and Research. 7(4), 393-413.

9. Al-Hawary, S.I.S. (2013b). The Roles of Perceived Quality, Trust, and Satisfaction in Predicting Brand Loyalty: The Empirical Research On Automobile Brands In Jordan Market. International Journal of Business Excellence (IJBEX). 6(6), 656-686.

10.Al-Hawary, S.I.S. Metabis, A. (2012). Service quality at Jordanian commercial banks: what do their customers say?. International Journal of Productivity and Quality Management. 10, 3, 307-334. 
11.Al-Hawary, S.I.S. and Aldaihani, F.M (2016). Customer Relationship Management and Innovation Capabilities of Kuwait Airways. International Journal of Academic Research in Economics and Management Sciences. 5(4), 201-226.

12.Al-Hawary, S.I.S. and Al-Menhaly, S.M. (2016). The Quality of E-Government Services and its Role on Achieving Beneficiaries Satisfaction. Global Journal of Management and Business Research: A Administration and Management, 16(11), 1-11.

13.Al-Hawary, S.I.S. and AL-SMERAN, W.F. (2016). Impact of Electronic Service Quality on Customers Satisfaction of Islamic Banks in Jordan. International Journal of Academic Research in Accounting, Finance and Management Sciences, 7(1), 170-188.

14.Al-Hawary, S.I.S. and Hussien, A.J. (2016). The Impact of electronic banking services on the Customers Loyalty of Commercial Banks in Jordan. International Journal of Academic Research in Accounting, Finance and Management Sciences, 7(1), 50-63.

15.Al-Mashari, M. and Zairi, M. (2000). The effective application of SAP R/3: a proposed model of best practice. Logistics Information Management, 13(3), 156-66.

16.Alshurideh, M. T., Al-Hawary, S.I.S., Batayneh, A.M.I., Mohammad, A. I. and Alkurdi, B. (2017). The Impact of Islamic Banks' Service Quality Perception on Jordanian Customers Loyalty. Journal of Management Research. 9 (2), 139-159.

17.Al-Smadi, Mohammad O. (2011). The Impact of E- Banking on The Performance of Jordanian banks. Journal of Internet Banking and Commerce, 16(2).

18.Amish, lyad Wasef (2005). Electronic banking in Jordan: development and challenges. Master Thesis, Yarmouk University, Irbid, Jordan.

19.Bagozzi, R.P. and Phillips, L.W. (1982) Representing and Testing Organizational Theories: A Holistic Construal, Johnson Graduate School of Management, Cornell University is collaborating with JSTOR to digitize, preserve and extend access to Administrative Science Quarterly.

20.Barnes, S.J. and Vidgen, R.T. (2002). An integrative approach to the assessment of E-commerce quality. Journal of Electronic Commerce Research, 3(3), 114-127.

21.Bartlett, J., Kotrlik, J. and Higgins, C. (2002). Organizational research: determining appropriate sample size survey research. Information Technology Learning and Performance Journal, 19(1), 43-51.

22.Chen, I.J. and Popovich, K. (2003). Understanding customer relationship management (CRM): People, process and technology. Journal of Business Process Management, 9(5), 672-688.

23.Chu, P.Y., Lee, G.-Y. and Chao, Y. (2012). Service Quality, Customer Satisfaction, Customer Trust, And Loyalty In An E-Banking Context. Social Behavior And Personality, 40(8).

24.Cletus, D. F. (2013). Customers' Perception of E-banking Adoption in Cameroon: An Empirical Assessment of an Extended TAM. International Journal of Economics and Finance, 5(1).

25.Comrey, A. (1978) Common methodological problem in factor analytic studies, Journal of Consulting and Clinical Psychology, Vol. 46 No.1, pp. 648-659.

26.Cristobal, E., Flavia, N.C., and Guinalı'u, M. (2007). Perceived e-service quality (PeSQ) Measurement validation and effects on consumer satisfaction and web site loyalty. Managing Service Quality, 17(3), 317-340.

27.Essam, E. I., Matthew, J., Kevin, I.N. I. (2006). Customers' perception of electronic service delivery in the UK retail banking sector, International Journal of Bank Marketing, Vol. 24 Iss: 7, pp.475 - 493.

28.Fjermestad, J., and Romano, N. (2002). An Integrative Implementation Framework for Electronic Customer Relationship Management: Revisiting the General Principles of Usability and Resistance. Paper presented at the Proceedings of the 36th Hawaii International Conference on System Sciences (HICSS "03) (C) IEEE.

29.Fonchamnyo, D.C. (2013). Customers' Perception of E-banking Adoption in Cameroon: An Empirical Assessment of an Extended TAM. International Journal of Economics and Finance, 5(1).

30.Gatewood, R. D. and Field, H. S. (1990). Human Resource Selection, The Dryden Press, Chicago, IL.

31.Goldenberg, B. (2000). What is CRM? What is an e-customer? Why you need them now.

32.Gould, J. D., and Lewis, C. (1985). Designing for usability: key principles and what designers think. Communications of the ACM, 28(3), 300-311. 
33.Gronroos, C. (1982). Strategic Management and Marketing in Service Sector, Marketing Science Institute, Cambridge, MA.

34.Hair, J.F. Jr, Anderson, R.E., Tatham, R.L. and Black, W.C. (1998). Multivariate Data Analysis, 5th ed., Prentice-Hall International, Upper Saddle River, NJ.

35. Hassanuddin, N. A., and Abdullah, Z. and Noor Hayati, H. (2012). Acceptance towards the Use of Internet Banking Services of Cooperative Bank. International Journal of Academic Research in Business and Social Sciences, 2(3).

36. Hijazi, N. M. (2007). The assessment of e-banking readiness in Jordan, Master Thesis, Faculty of Economics and Administrative Sciences, Yarmouk University.

37.Jazani, N., Sobhanifard, Y. and Kharazian, M. A. (2012). Analyzing the Relationship Between the Level of E-banking and Customer Satisfaction From E-banking Service Quality in Iran. China-USA Business Review, 11(5), 643-653.

38.Lee, G.-G., Lin, H.-F. (2005). Customer Perception of E-Service Quality In Online Shopping. Emerland Group Publishing Limited, 33(2), 161-176.

39.Lee-Kelley, L., Gilbert, D., and Mannicom, R. (2003). How E-CRM can enhance customer loyalty? Marketing Intelligence and Planning ABI/INFORM Global, 21(4/5), 239-248.

40.Ma, Z. and Zhao, J. (2012). Evidence on E-Banking Customer Satisfaction in the China Commercial Bank Sector. Journal Of Software, 7(4).

41.Nunnally, J.C. and Bernstein, I.H. (1994). Psychometric theory, $3^{\text {rd }}$ ed., McGraw Hill, New York.

42.Parasuraman, A., Zeithaml, V.A. and Malhotra, A. (2005). ESQual: A multiple item scale for assessing electronic service quality. Journal of Service Research, 7(3), 1-21.

43.Purba, S. (2001). Architectures for E-Business Systems, Building foundations for tomorrow's success, CRC Press.

44.Renner, D. (2000). Customer relationship management: a new weapon in your competitive arsenal. Siebel Magazine, 1(2).

45.Rosu, A. M. (2011). The Quality of the Relationship Between Banks and Customers. Economical and Administrative Sciences, 1, 161-173. [Online]

46.Rust, R. T., Zahorik, A. J., and Keiningham, T. L. (1995). Return of quality (ROQ): making service quality financially accountable. Journal of Marketing, 59(58-70).

47.Salhieh, L., Abu-Doleh, J. and Hijazi, N. (2011). The assessment of e-banking readiness in Jordan. International Journal of Islamic and Middle Eastern Finance and Management, 4(4), 325-342.

48.Santos, J. (2003). E-service quality - a model of virtual service dimensions. Managing Service Quality, 13(3), 233-246.

49.Scullin, S., Allora, J., Lloyd, G.O., Fjermestad, J. (2002). Electronic customer relationship management: benefits, considerations, pitfalls and trends. Proceedings of the IS One World Conference, Las Vegas, Nevada, April 3-5, CDROM.

50.Swaid, S.I. and Wigand, R.T. (2009). Measuring the quality of eservice: scale development and initial validation, Journal of Electronic Commerce Research, 10 (1), 13-28.

51.Wang, Y., Lo, H. P., Chi, R., and Yang, Y. (2004). An integrated framework for customer value and customer-relationshipmanagement performance: a customer-based perspective from China. Managing Service Quality, 14(2/3), 169-182.

52.Yaeckel, B., Kania, D. and Allen, C. (2002). One to One Web marketing, second Edition: Build a Relationship Marketing Strategy One Customer at a time, Wiley Computer Publishing, John Wiley and Sons, Inc.

53.Zeithaml, V.A., Parasuraman, A. and Malhotra, A. (2000). E-service quality: Definition, dimensions, and conceptual model. Working Paper, Marketing Science Institute, Cambridge, M.A.

54. Zeithaml, V.A., Parasuraman, A. and Malhotra, A. (2002). Service quality delivery through web sites: a critical review of extant knowledge. Journal of the academy of the marketing science, 30(4), 362375. 